\title{
An environmental analysis of the acaraú river basin, Brazilian northeastern region
}

\begin{abstract}
The rivers and their watersheds are fundamental elements of socioeconomic activities. In this article, we analyze the hydrographic basin of the Acaraú River, situated in the northeast of Brazil, from its geoenvironmental aspects, based on the perspective of the geosystem. In this perspective, a geoenvironmental picture of the hydrographic basin in question is presented, as well as the environmental problems that characterize it, postulating the need to carry out this type of survey to define the basin as a fundamental planning unit. The Acaraú River basin has particular characteristics, since it is located in a poor and extremely populous semi-arid region, which results in socio-environmental stress, whose main consequence is the environmental degradation of the fluvial course. The regional authorities need to be aware of the geoenvironmental elements raised in order to reverse this framework of socio-environmental degradation of water resources and to allow territorial growth based on sustainable development.
\end{abstract}

Volume 4 Issue 3 - 2020

Vanda Claudino-Sales,' Ernane Cortez Lima, ${ }^{2}$ Simone Ferreira Diniz, ${ }^{2}$ Isorlanda Caracristi, ${ }^{2}$ Jamersson Francisco Ribeiro Brito ${ }^{2}$

'Universidade Federal do Ceará, and Master on Geography of the State University of Acarau Valley, Brazil

${ }^{2}$ State University of Acarau Valley, Brazil

Correspondence: Vanda Claudino-Sales, Universidade Federal do Ceará, and Master on Geography of the State University of Acarau Valley, Brazil, Email vcs@ufc.br

Received: May 18, 2020 | Published: June 01, 2020

Keywords: acaraú river water shed, Brazilian northeast, geoenvironmental analysis, environmental degradation

\section{Introduction}

River processes are one of the most active elements in the formation of the earth's landscape. Indeed, rivers are the most important agents in the transportation of weathered materials from high to low areas and from continents to the ocean. In this journey, they exhume and lower surfaces, create landscapes, recycle materials and provide the formation and existence of important ecological niches and different ecosystems. In addition to their natural importance, rivers and their basins are fundamental elements of socioeconomic activities. Indeed, basins are considered the most appropriate space planning unit, as it allows multidisciplinary integration between different planning and management systems, study and environmental activities. ${ }^{1,2}$ From this perspective, the definition of economic and environmental planning based on the hydrographic basin is analyzed not only in the hydrological dimension associated with the behavior of water flows in their physical and limnological processes. Considering hydrographic basins as a planning unit, the fluvial and hydrographic approach is extended to the whole environment, potentiating the insertion of this natural element in the decision-making and in the ways of appropriation of the fluvial space and the use of the geographic space in a broadway.

Hydrographic basins lend themselves majestically to environmental planning, as they are space units that are easy to recognize and easy to characterize, considering that no area of the earth's surface is inserted outside of a basin. ${ }^{3}$ The hydrographic basin considered as a planning unit also enables the preservation of water resources, ${ }^{4}$ besides the intended control of natural and socioeconomic resources, favoring the integration of soil and water use and management practices with social organization. Thus, basins are an important space unit for management that involves the conservation of natural resources, or the indication of the degree of degradation due to the use practices of these resources. ${ }^{5}$

To adequately carry out the management of basins, as well as environmental planning based on this natural element, one must consider that a basin represents a systemic whole. ${ }^{6}$ Researches on this topic with systemic and integrated perspectives enable the elaboration of proposals for actions based on the dynamics and functioning of the basin, promoting control of the use of natural resources based on the potentialities and limitations of these resources.

The river basin seen as a system highlights the relationships of its physical and biogeographical elements with the socioeconomic variables in the context of the geographical space in which they are inserted. ${ }^{7}$ In reality, a river basin forms a system in which the mutual relations among its structural components enable the integrated analysis of the environment, allowing an accurate evaluation of its aspects, both physical and economic and social. Therefore, it must be conceived as a "multi-composed" system that includes water andother elements of geo-ecological potential overlapped, dialectically, by socio-political and economic aspects. ${ }^{2}$ Integrated systemic studies that have river basins as an element and are focused on planning and territorial arrangementmay be fundamental for the establishment of public policies that aim a better use and occupation of the territory, seeking sustainable development and the preservation of natural resources. This paper presents considerations associated with systemic studies, of the "geoenvironmental" type, in the Acaraú river basin, located in the State of Ceará, Brazilian northeasternregion (Figure 1). The geosystems characterization that defines the exposed approach is explained in the methodology item below.

\section{Methodology}

This study was carried out based on environmental analysis and the perspective of systemic and geosystems analysis. The general systems theory was systematized by Bertalanfy. ${ }^{8}$ Today it represents a scientific paradigm that integrates processes, flows, matter and energy, which has been integrated into the most diverse sciences, including the natural sciences. The general systems theory implies the abandonment of fragmented and isolated studies of nature, promoting holistic and integrated studies instead. It may be said that a system is a set of phenomena that occur through flows of energy and matter, which produce mutual relations among its components. Capra summarizes the key characteristics of systemic thinking, citing that it is about the 
passage from parts to the whole, the whole presenting characteristics or properties that cannot be understood by the reduction in smaller parts.

Sotchava ${ }^{9}$ associated the social and anthropic elements to natural studies, naming the set of geosystems. The geosystems analysis is based on the idea of interaction between the environmental variables of the natural environment (geology, relief, hydrography, vegetation, soils) and the forms of land use and occupation, to identify impacts and changes in natural dynamics. The theoretical and methodological conceptual bases of the environmental analysis presented is based on the holistic and integrated perspective of the geographic space, aiming at understanding the interaction between processes and their relationships and correlations. Bertrand ${ }^{10}$ considered geosystems as an analyzable territorial unitpossible to be delimited. In this perspective, it is defined in this work the Acaraú river basin, in the State of Ceará, Brazilian northeasternregion, as a space-territorial unit, which should be considered as such by the authorities to promote sustainable regional environmental planning. The perspective is to provide subsidies for better use of the Acaraú river to the public sectors responsible for planning and managing the economic and social activities in the area of the insertion of its basin.

To achieve this goal, some technical steps of scientific work were carried out:

i. Bibliographic research about the whole basin, in particular on geology, geomorphology, soil and use and occupation of the geographical space;

ii. Cartographic analysis of the elements that make up the geoenvironment. In this perspective, the delimitation of the Acaraú river basin was carried out using the r.watershed/GrassGIS tool of the Qgis 2.18.11 software, with the SRTM (Shuttle Radar Topography Mission) Digital Elevation Model distributed by the USGS (United States Geological Survey) for the study area. The development of the geology and geomorphology maps was based on cartographic data from IBGE (Brazilian Institute of Geography and Statistics), which were confronted with the referred elevation data for the delimitation of the respective geological and geomorphological units, through vector digitalization processes. The organization and presentation of the maps were implemented with the print composer of Qgis 2.18.11. iii. Fieldwork along the river basin, at points of the high, medium and low courses, for area recognition and data survey, using maps, GPS, notebook and camera.

The results of this methodological and technical production and the scientific surveys carried out are expressed in the following items.

\section{A GEO-environmental analysis of the acaraúsemiarid river basin}

The Brazilian northeastern region is one of the three nuclei of semiarid regions in South America, inserted in a context of a predominantly humid continental area. It represents the phytogeographic province of the caatingas, with high and constant average/year temperatures. The region is characterized by low humidity levels. There is a relative scarcity of annual rainfall; as well as irregular rainfall over the years; with long periods of water shortage; besides soils with physical and chemical problems and lack of fluvial perenniality.

The Acaraú river basin, located in the northern segment of the Brazilian northeastern region (State of Ceará), has about $14,427 \mathrm{~km}^{2}$ of area. The main river is $315 \mathrm{~km}$ long in a south-north direction and is a fifth-order stream. ${ }^{11}$ It has itsprincipal spring located in mountainous reliefs with about $800 \mathrm{~m}$ of altitude. It presents a river regime of floods during the summer-autumn rains, with an average flow rate of $4.451 / \mathrm{s}$ / $\mathrm{hm}^{2}{ }^{12}$

The Acaraú river drains dry land (arid, semiarid and sub-humid dry), bathing 25cities, among them, Tamboril, Pires Ferreira, Sobral, Santana do Acaraú, Bela Cruz, Acaraú (Figure 1). It presents hydrological dynamics that depend on the spatial-temporal renewal of the rains, basically from the runoff at certain periods of the year. It is characterized, therefore, by a seasonal, intermittent regime, which influences the hydro-environmental potentials of the drained region. The river basin is composed of 12 dams with a total water capacity of approximately $1,443,763,000 \mathrm{~m}^{3}$, which perennialize the river course. ${ }^{13}$ The climate of the region, according to Strahler's ${ }^{14}$ classification, entrusted by Zanela ${ }^{15}$ is of the semiarid type. It is marked by the occurrence of two climatic seasons: a short and irregular rainy season that occurs in autumn (months from March to May), and a prolonged dry season (at least 10months of the year) with high evaporation, low relative humidity and high temperatures.

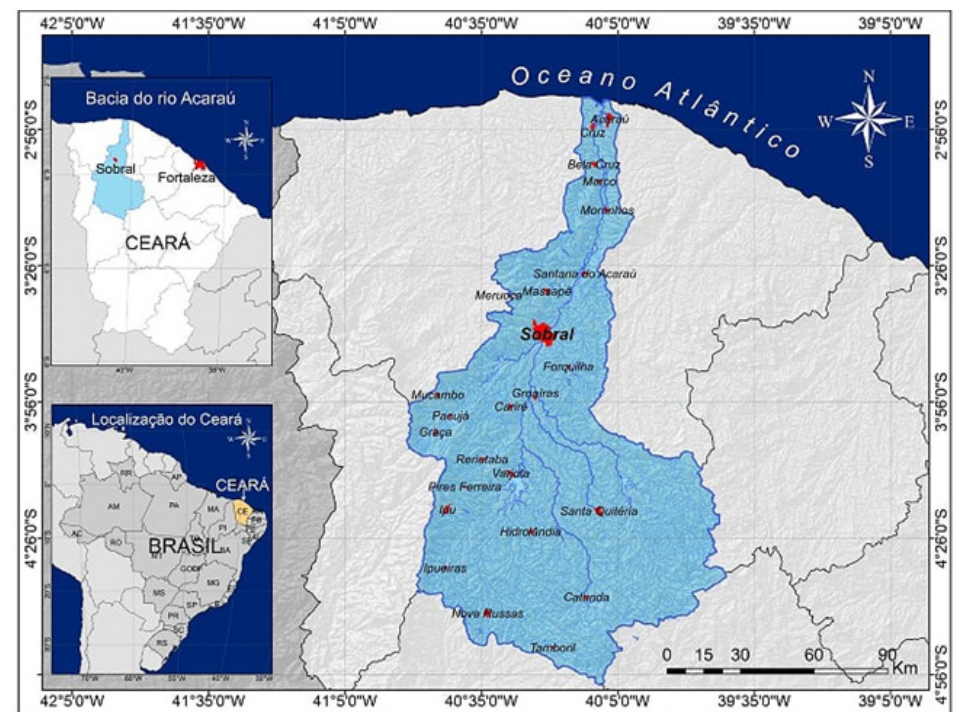

Figure I Location of the Acaraúriver basin, Brazil. 
Throughout the basin, average temperatures oscillate around $27^{\circ} \mathrm{C}$, but higher values occur, as in the municipality of Sobral, where the monthly average is $28.9^{\circ} \mathrm{C} .^{16}$ The average annual rainfall in the river basin area is between $670 \mathrm{~mm}$ and $940 \mathrm{~mm} \cdot{ }^{13,17} \mathrm{In}$ its lower part, the climate is more humid, the rainy tropical type. The average relative humidity varies from levels $<50 \%$ to $>80 \%{ }^{18}$

The regional geology presents a predominantly crystalline structure, formed mainly by igneous and metamorphic rocks, the main types being granite, migmatite, paragneiss and orthogneiss. These lithologies correspond to approximately $90 \%$ of the basin area, ${ }^{19}$ (Figure 2). The main aquifers are the alluvial, the Jaibaras dam, and the tertiary sedimentary deposits of the Barreiras Formation, the former being responsible for about $50 \%$ of the exploitable reserve in a normal year. ${ }^{11}$

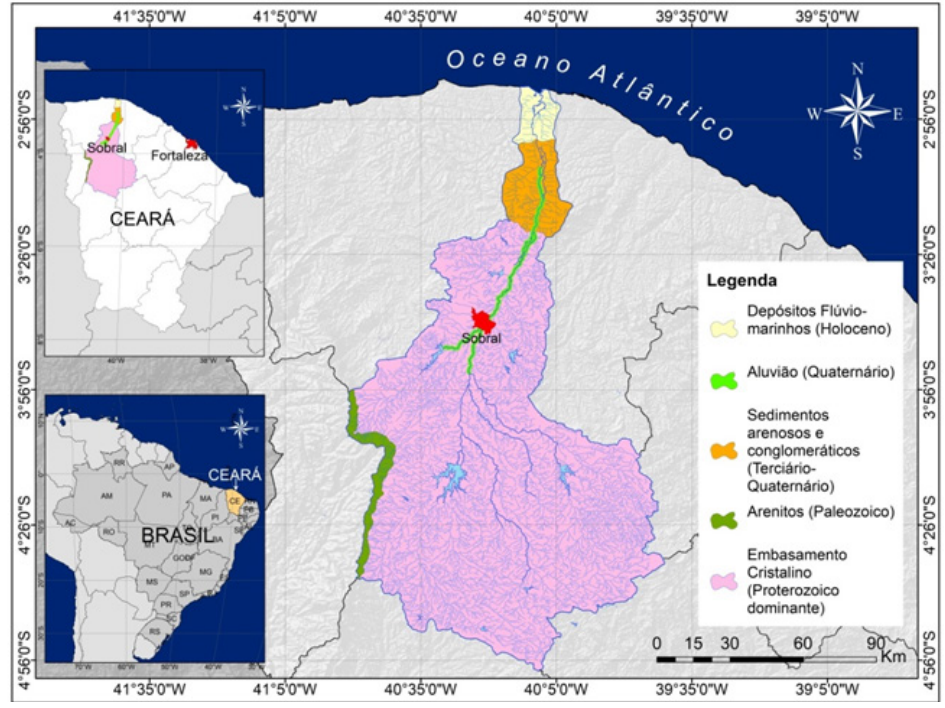

Figure 2 Simplified geological map of the Acaraú river basin.

Regional failures show North-South trend, tending to NortheastSouthwest one. One important failure concerns the shear zone SobralPedro II, of Neoproterozoic age. This failure, which represents a segment of the Transbrasiliano Lineament, which cuts Brazil from the Northeast to the Southwest, is associated with the Brasiliana Orogeny, which connected the Gondwana continent at the end of the Proterozoic eon. ${ }^{20}$ It represents the most important of all the tectonic events that hit the Northeast of Brazil, having been responsible for intense bending, metamorphization of older rocks and creation of shear zones, such as the Sobral-Pedro II fault. ${ }^{21}$ This fault was reactivated in the Cretaceous period,,$^{22,23}$ and around it, the mid-course segment of the Acaraú River is embedded.

Other important structural features in the river basin are represented by the succession of pre-Cambrian and paleozoichosrts and grabens whose ensemble corresponds to the orogenic body of Acaraú and associated Sobral platform. ${ }^{19}$ Two important batholiths are located in the Pre-Cambrian superior graben of Jaibaras. They constitute Serra da Meruoca-Rosário and Serra do Carnutim. Paleozoic rocks also occur, bordering the western portion of the basin, which are represented by the Serra Grande group in the Silurian-Devonian period, ${ }^{19}$ (Figure 2). Sedimentary packages from the Tertiary-Quaternary period also occur in the low course, making up the Barreiras formation. Finally, it should be noted that they are explored as mineral resources in the clay, limestone and ornamental rocks area. ${ }^{24}$

Regarding the morpho-structural aspects, the relief of the Acaraú river basin presents characteristics that depend on geological and paleoclimatic factors and past and present morphoclimatic processes. The morpho-structural organization is derived from the Cretaceous period, associated with the tectonic event that produced the Gondwana/Pangea division. During this event, rifts were formed in the countryside of the northeastern region, and vast sectors of the regional territory were erected in the form of rift shoulders. ${ }^{23,25-27}$ During the Tertiary period, the morphogenetic processes, in the priority of mechanical nature, typical of countryside areas ${ }^{28}$ eroded a portion of these elevated sectors, producing pediplains. The sectors formed by more resistant rocks, such as the Neoproterozoic granitoid, remained in the landscape, creating crystalline massif (mountainous relief). The correlative material of this erosive process was deposited along the coastal zone, forming the tertiary deposits that make up the Barreirasformation. The Quaternary climate changes, producing sea-level changes, shaped the coastal zone ${ }^{25-27}$ This geomorphological evolution characterizes the northern Northeast and is representative of the geomorphological framework of the Acaraú river basin now under analysis.

The basin has a topography with strong declivity in some stretches, where mountainous regions occur. In fact, in this basin occurs the largest hypsometric amplitude of the state, with altitudes that vary from $0 \mathrm{~m}$ in the coast to $1,145 \mathrm{~m}$ in the Pico do Oeste, located in Serra das Matas (average altitude of $900 \mathrm{~m}$ ), municipality of MonsenhorTabosa, which represents the highest altitude registered in the State of Ceará, and which is partially supported by Neoproterozoic granite. The main river springs are found in this feature. Another important mountainous region is located in the basin's central part, which is the Serra da Meruoca, located in the city of Sobral, which is supported by the Neoproterozoic granitic stock called Meruoca granitoid. This relief was raised in the Cretaceous period during the division of Pangea when probably the granite was placed in sub-area conditions..$^{25}$ It represents a quadrangular feature controlled by failures and shear zones on practically all slopes, forming a mountainous region of the humid forest type ${ }^{16}$ (Figure 3). 


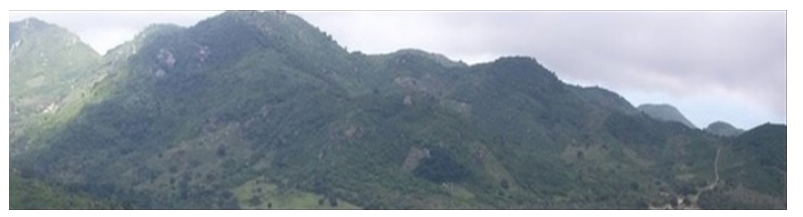

Figure 3 Serra da Meruoca Massif, with an average altitude of 900 m, located in the central segment of the Acaraú river basin, from where tributaries flow towards the central bed. Photo: Claudino-Sales, V.

In terms of mountainous relief, there is also, in the western segment, the Ibiapaba sedimentary plateau, supported by the Serra Grande group, of Paleozoic age. The relief in Serra da Ibiapaba is of the Klint type, which represents cuestiform features with slope and foothills supported by crystalline and non-sedimentary rocks. ${ }^{27,29}$ It represents an area that was erected during the division of Pangea, in the Cretaceous period, in which the crystalline rocks proved to be more fragile than the sedimentary rocks and were lowered by tertiary morphogenesis, leaving the sedimentary material in rebound. ${ }^{27,29}$ It represents one of the wettest sectors of the State of Ceará, where several tributaries of the Acaraú river have springs $^{16}$ (Figure 4).

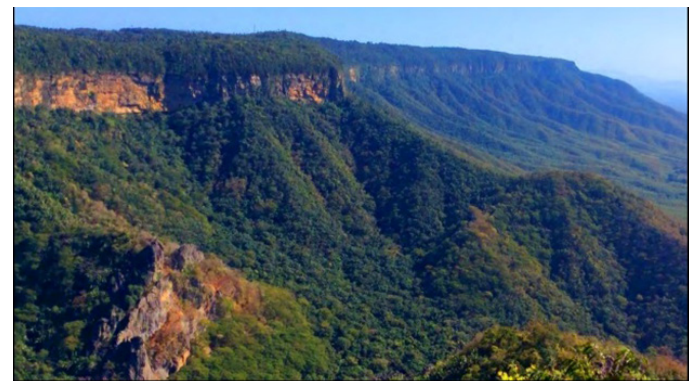

Figure 4 lbiapaba plateau represents a glint shaped by Paleozoic sandstones, which form the cornice, having in the slope and the base crystalline limestone (metamorphic) rocks of pre-Cambrian age. Some tributaries of the Acaraú River are located in this relief, representing anaclinal rivers. Photo: ClaudinoSales, V.

Despite these mountainous reliefs, most of the basin area is below $200 \mathrm{~m}$ in altitude. The slope is greatly reduced towards the coast, with the predominance of soft relief in these distal segments, with the Sertaneja pediplain occurring for the most part. The Sertaneja surface, modeled during the Tertiary period, presents reliefs of the inselbergs type, which presents altitudes of up to $500 \mathrm{~m}$, but it is below $200 \mathrm{~m}$ in the lower segments, which are the dominant ones (Figure 5).

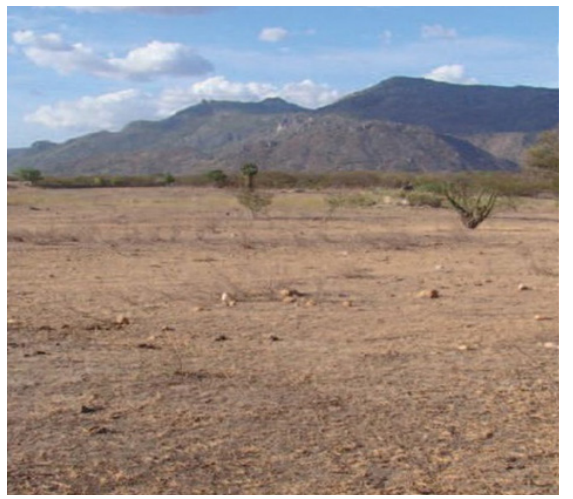

Figure 5 Sertaneja pediplain surface with inselberg, where mechanical morphogenesis predominates, in the southern segment of the Acaraú basin. The soils are lithoic and the vegetation is the shrubby caatinga. The whole creates a natural landscape typical of the semiarid region of Ceará. Photo: Claudino-Sales, V.
Other geomorphologic features are the coastal tablelands, modeled on the Barreirasformation, and the sea-river plain. There are also dunes and beaches composed ofquaternary sand in the coastal plain. Also, the presence of alluvium is observed in the riverbank's medium and low course. Figure 6 illustrates the geomorphological diversity of the Acaraú basin. The predominant soils in the area of the Acaraúriver basin ais the litholic, stony and erosion-susceptible Neosol. In the river valley, medium-deep and moderately acidic flowing Neosol dominates. Quartzarenic Neosol and saline soil occur in the coastal region, unconsolidated and easily transported due to the almost absence of riparianvegetation. ${ }^{3,24,30}$ The vegetation is characterized by the presence of xerophilous formation of the Brazilian biome Caatinga. The caatinga represents predominantly deciduous vegetation that colonizes shallow and stony soil with extreme water deficiency for most of the year. ${ }^{31}$ The indigenous-origin term means "open, clear forest", which contrasts with closed and dark forests. This vegetation type is present in most areas of the middle and also in a smaller proportion in the low course of the basin. The riparian vegetation has the marked presence of carnaúba palm (Copernicia prunifera) and oiticica (Licaniarígida) (Figure 7). The Acaraúriver presents, for most of its course, a tangle of channels that create a dendritic pattern. In its high and medium course, the river presents high levels of rainstorm, which causes flooding in riverside cities. ${ }^{13}$ In its low course, the siltation of the river by the dunes gives rise to the appearance of numerous intertwined channels ${ }^{17}$ (Figure 8). The mouth is characterized by sinuous drainage of channels, where the floodplain widens and, penetrated by the tides, becomes an extensive mangrove swamp.

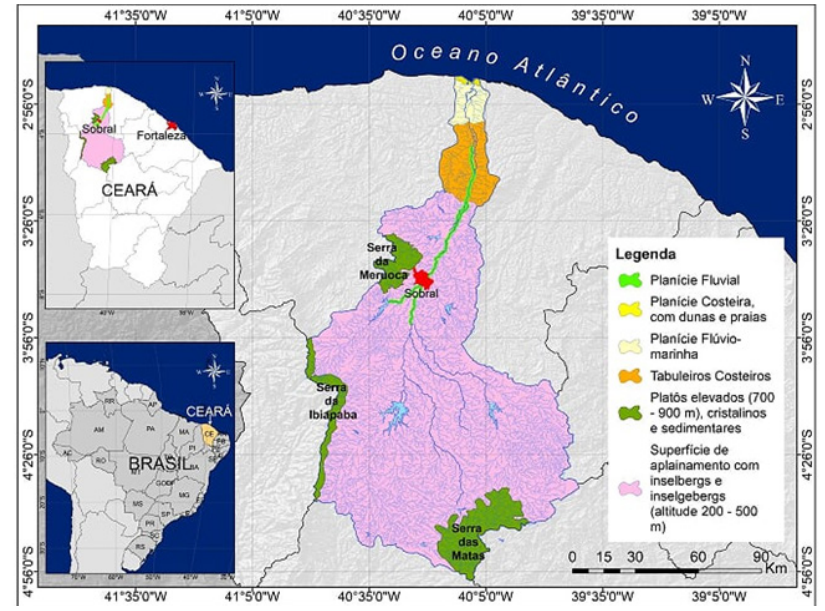

Figure 6 Synthetic geomorphologic map of the Acaraú river basin.

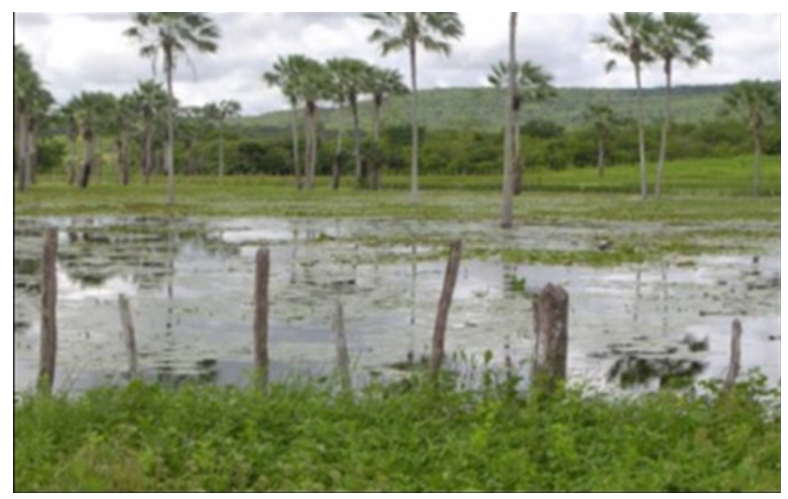

Figure 7 Floodplain (alluvial sediment on the larger bed) occupied by carnauba palm vegetation (Copernicia prunifera), on the Acaraú river. 


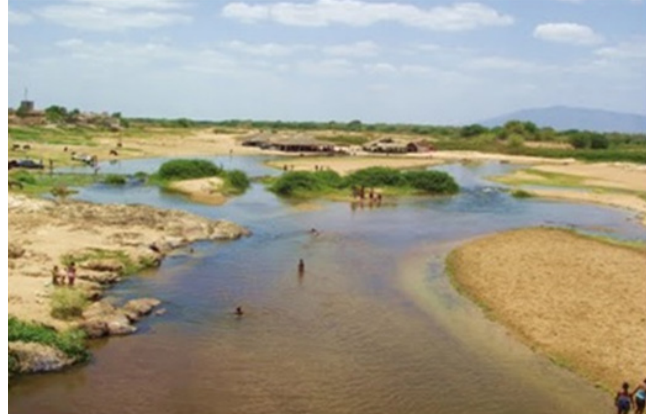

Figure 8 Acaraú river during the dry season in the city of Santana do Acaraú, showing an intertwined pattern and larger bed, as typical of intermittent rivers.

In terms of land use/occupation, the Acaraú river basin has its fundamental support in the primary sector of the economy. The area is characterized by extensive farming, agro-extraction and small subsistence farming. ${ }^{11}$ In urbanized sectors, trade and services predominate. Human occupation outside urban centers is extremely rare.

With restricted use of irrigation due to lack of technical means, absence of adequate public policies and economic restrictions on the part of the largest portion of the population, the possibilities of agriculture at the end of the rainy season are restricted to the use of river floodplains and damsbank, where short-cycle crops dominate This is why the practice of so-called ebb and flowfarming is common, which, as the water level goes down, gradually moves from the larger bed to the smaller bed of the watercourse. Through this practice, widely used along the main channel of the Acaraú river and its tributaries, farmers take advantage of the sub-surface's moisture reserves. ${ }^{13}$ Besides, vegetal extraction occurs in floodplain areas, especially carnauba straw, but in a disordered manner. ${ }^{11}$

\section{Environmental problems in the acaraú river basin}

The Acaraú River basin has been the object of intense "domestication" over the years, aiming to gain new land for agriculture and urbanization, provide water for (human, animal, domestic and industrial)supply, minimize the effects of floods and droughts, provide fish farming, fishing and irrigation of agriculture and ensure the perennialization of the river. Such situations are represented by (1) the construction of reservoirs of water of the type dams, which occurred mainly during the 1940s, 1950s and 1960s, (2) the channeling of the riverbed in urban areas aiming to expand the extension of urbanized areas in cities cut by the river and (3) the construction of piping areas and sub-areas to ensure the drainage and discharge of effluents in urban and industrial areas along the river valley. The works based on this domestication concept resulted and result in necessary adjustments of the river course dynamics, reduction of the variety of biota, changes in ecosystems and degradation of water quality. These factors are characterized by adjustments and changes in river geomorphologic and sedimentological processes, such as changes in the river balance profile, erosion, silting, meandering formation and riverbanks, changes in river plain width, increase or decrease in river flow speed and material transport. The river has been undergoing interventions for decades without any studies on its geomorphological, hydrological and paleoclimatic evolution.

In fact, from the conservation point of view, it should be noted that the Acaraú river basin presents a series of environmental problems. In the low course of the river, there is the action of real estate speculation and the development of tourism destroying natural environments, as well as shrimp farming, which deforests mangroves and pollutes the estuary. There is also disorderly growth of population centers and agro-industrial increase associated with the management of irrigation in the irrigated perimeters existing in the distal segment of the river, resulting in soil and water pollution.

In other sectors, problems such as deforestation in the riverbank, soil erosion, desertification and pollution of the river due to domestic sewage and urban runoff water, as well as by waters served from agricultural activities and industrial effluents occur. ${ }^{3}$ There is also deficiency or non-existence of systematic garbage collection and inadequate solid waste disposal. There is also the presence of illegal private dams of river courses associated with the river basin, which changes the local hydrological dynamics, ${ }^{3}$ as well as extraction of sand from river valleys for use in civil construction ${ }^{17}$ (Figures 9\&10).

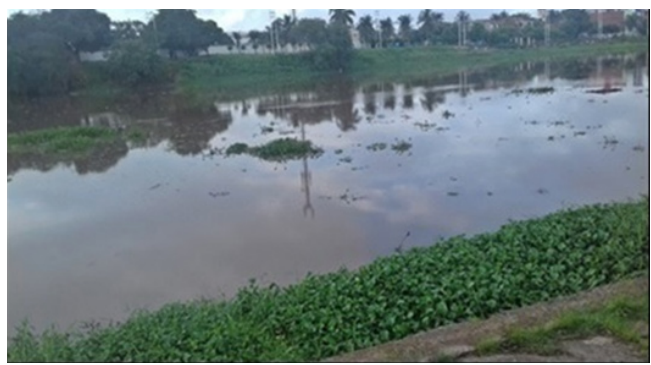

Figure 9 Acaraú river extremely polluted by sewerage in the city of Sobral, with a high degree of eutrophication.

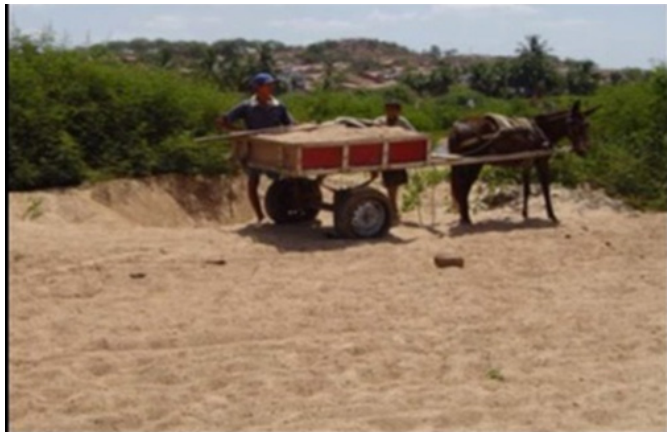

Figure 10 Sand removal from the Acaraú river bed in the city of Sobral, during the dry season.

The surface runoff of the drainage basin of the Acaraú river is regularized by the various dams arranged along its river course. The fluvial contribution originating from these dams during the rainy season indicates a flow of about $31 \mathrm{~m}^{3} / \mathrm{s}$ during the rainy season and about $1 \mathrm{~m}^{3} / \mathrm{s}$ during the dry season..$^{32}$ Thus, the river practically disappears during the dry season, resulting in the silting of the river valley, which potentially implies flooding and loss of quality of the dams downstream of the silted stretches. During the rainy season, the large increase in the flow may, in turn, produce erosion and loss of environments and ecosystems in riparian areas.

In general terms, the degradation of the Acaraú river can be summarized in the following terms:

i. Discharge of water from agricultural activities, characterized by the presence of herbicide, fertilizer, pesticide, agrochemical and agricultural defensives in general, which are transported by rainwater to the river bed or infiltrate the subsoil; 
ii. The existence of domestic sewer, which represents the main introducers of biodegradable organic compounds into the aquatic environment;

iii. The deficient collection of garbage in urban centers, as well as the absence of sanitary landfill, with part of the garbage produced being deposited near the river channel;

iv. Industrial and agro-industrial dump, in addition to washed waste from public and private slaughterhouses that are thrown out into the open, which are incorporated into the drainage network or are directly dumped in the riverbed. On the coast, the shrimp farming throws thousands of liters of contaminated water into the river estuary;

v. Lack of sewage in urban areas, with served water being discharged directly into the river bed, constituting a serious focus of water pollution, making the water quality unsuitable for multiple uses.

This socio-environmental reality identified in the Acaraú river basin is not exclusive to this water resource, but rather characterizes the vast majority of the hydrographic basins in the Northeast of Brazil, as previously identified by research on these themes, such as Nascimento, ${ }^{2,3}$ Lima and Silva ${ }^{1}$ and Mesquita et al..$^{33,34}$

\section{Conclusion}

Water is a fundamental resource in the process of structuring and socioeconomic, political and cultural organization of the northeastern Brazilian semiarid region, of which the Acaraú river basin is a great example.

However, it can be seen that surface and subsurface water reserves in the Acaraú river basin are threatened due to the demand for water and, mainly, by the disorderly occupation of the biophysical environment. The removal of the substrate from the riverbed and riverbanks, deforestation for agricultural use, woody extraction, the damming of streams and the decomposing garbage in sections of rivers - mainly in the vicinity of cities - decrease the volume of water and silt up the river. In this spectrum, desertification, the greatest consequence of environmental degradation in semiarid and sub-humid dry areas, is a strong and real threat in all the territory drained by the river. Furthermore, it is noted that due to the sanitary problems of the various basins, the high temperatures and the decrease in the flow of water in the second half of each year - allied to the deposition of waste and the habits of the population - the chances of the emergence of diseases linked to water require care by the competent authorities. In addition to human health problems, water contamination affects the quality and biological diversity, while fishing activity is compromised and the use of water for recreational and tourist activities is negatively affected. The development of an integrated action plan based on the "river basin" unit is necessary and indispensable; through the involvement of public agents, the business sector and organized civil society in associations, considering the environmental laws and the local reality. Fundamentally, the basin should be considered as management and geo-environmental planning unit. Thus, the environmental and life quality of the populations can be optimized.

Finally, the conclusion is that the environmental management of the Acaraú river basin must be guided by the geo-environment and the geosystems that characterize it, adopting a model of sustained development that is not only technical - only hydric or limnological - but managed by understanding the semiarid conditions and the geosocioenvironmental characteristics of the regional territory. Basically, in an undeniable way, the river basin should be considered as the main anchor of territorial development.

\section{Acknowledgments}

None.

\section{Conflicts of interest}

There is no conflict of interest between the authors.

\section{Funding}

None.

\section{References}

1. Lima EC, Silva EV. Estudos geossistêmicos aplicados à bacias hidrográficas. Revista Equador. 2015;4:3-20.

2. Nascimento FR. Os recursos hídricos e o tropico semiárido brasileiro. $G E$ Ographia. 2012;14(28):82-109.

3. Nascimento FR, Cunha SB, Souza MJN, et al. Diagnóstico geoambiental da bacia hidrográfica semiárida do Rio Acaraú: subsídio aos estudos sobre desertificação. Boletim Goiano de Geografia. 2008;28:41-62.

4. Tonello KC. Hydro-environmental analysis of the Cachoeira das Pombas hydrographic basin, Guanhães, MG. Master's Dissertation, Federal University of Viçosa; 2005.

5. Piégay $\mathrm{H}$, Kondolf $\mathrm{M}$, Minear $\mathrm{T}$, et al. Trends in Publications in Fluvial Geomorphology Over Two Decades: A Truly New Era in the Discipline Owing to Recent Technological Revolution? Geomorphology. 2015;248(1):489-500.

6. Pires JSR, Santos JE, Del Prette ME. The use of the hydrographic basin concept for the conservation of natural resources. In: Schiavetti A, et al. Editors. Hydrographic basin concepts: theories and applications. Editora Ilhéus; 2008.

7. Lourenço RM. Physical - conservationist diagnosis as a contribution to the analysis of degradation in the medium course of the hydrographic basin of the Aracatiaçú river (CE) - Brazil. Dissertação (Mestrado em Geografia). Universidade Federal do Ceará: Fortaleza; 2013.

8. Bertalanfy L Von. General System Theory. New York: George Braziller; 1969.

9. Sotchava VB. The method in question. The study of geosystems. University of São Paulo, Institute of Geography: São Paulo; 1977.

10. Bertrand G. Paisagem e geografia física global: esboço metodológico. Caderno de Ciências da Terra. Instituto de Geografia da Universidade de São Paulo. 1972;13.

11. COGERH (Companhia de Gestão dos Recursos Hídricos do Estado do Ceará). Regional Notebook of the Acaraú Basin. INESP: Fortaleza; 2009.

12. SRH (Secretaria de Recursos Hídricos do Estado do Ceará). Hydrological Atlas of the State of Ceara. Fortaleza: SRH; 2012.

13. Sucupira PAP, Pinheiro LS, Rosa M de F. Morphometric characterization of the medium and low course of the Acaraú River. Ceará - Brazil. III National Symposium on Geomorphology, Rio de Janeiro. 2006.

14. Strahler AN. Physical Geography. New York: Wiley; 1952.

15. Zanela ME. The climatic characteristics and water resources of the State of Ceará. In: Silva JB, et al. Editors. Ceará: a new geographical look. Fortaleza: Editions Democritus Rocha. $2^{\text {nd }}$ edn. 2007;169-188.

16. Lima EC. A importância das serras cristalinas no semiárido do Nordeste, especialmente no Ceará-Brasil. Revista da Casa da Geografia de Sobral (RCGS). 2014;16(1):89-100. 
17. Sobrinho JF. Geomorphological compartmentalization of the Acaraú River Valley. Water division and small farmer. Mercator. 2006;10:91-92.

18. Mota lhso, Valladares G. Vulnerabilidade a degradação dos solos na Bacia do Rio Acaraú, Ceara. Revista Ciência Agronômica. 2011;42:39-50.

19. CPRM (Serviço Geológico Brasileiro). Geological map of the State of Ceará. CPRM: Fortaleza; 2003.

20. Brito-neves BB. América do Sul: quatro fusões, quatro fissões e o processo acrecionário andino. VII Simpósio Nacional de Estudos Tectônicos, SBG, Bahia. 1999;11-13.

21. Brito-Neves BB. Regionalização geotectônica do Pré-cambriano Nordestino. Tese de Doutorado, Instituto de Geociências/Universidade de São Paulo; 1975.

22. Szatmari P, Françolin JBL, Zanotto O, et al. Evolução Tectônica da margem equatorial brasileira. Revista Brasileira de Geociências. 1987;17(2):180-188.

23. Peulvast JP, Claudino-Sales V. Stepped surfaces and palaeolandforms in the northern Brazilian Nordestee: constraints on models of morphotectonic evolution. Geomorphology. 2004;62:89-122.

24. Diniz SF, Moreira CA, Corradini FA. Susceptibilidade erosiva do baixo curso do Rio Acaraú. Geociências. 2008;27(3):355-367.

25. Claudino-Sales V. Megageomorfologia do Nordeste Setentrional Brasileiro. Revista Geografia. 2018;35:442-454.
26. Claudino-Sales V. Megageomorphology of the State of Ceará. São Paulo: NEA Edições; 2016.

27. Claudino-Sales V. The coasts of Ceará: Geomorphological evolution of the coastal area of the State of Ceará: from long term to short term. Tese de Doutorado, Universidade Paris-Sorbonne; 2002.

28. Melo MS, Claudino-Sales V, Peulvast JP, et al. Continental morphogenetic processes and products. In: Souza CRG, Suguio K, Oliveira AMS, et al. Editors. Quaternary of Brazil. São Paulo: Holos; 2005. p. 258-281.

29. Claudino-Sales V, Lira MV. Megageomorfologia do Noroeste do Estado do Ceará. Caminhos de Geografia. 2011;4:10-21.

30. Diniz SF, Rueda J, Caracristi I. Physiographic study of the northern region of the State of Ceará (Rio Acaraú). Revista Geonorte. 2014;10:298-302.

31. Fernandes A. Phytogeographic themes. Stylus Comunicações: Fortaleza; 1990.

32. Molissani MM, Cruz ALV, Maia LP. Estimativa da descarga fluvial para os estuários do Rio Ceara, Brasil. Arquivos de Ciências do Mar. 2006;39(12):53-60.

33. Mesquita FNS, Caracristi I, Diniz SF, et al. Análise Socioambiental do Médio Curso do Rio Acaraú, Ceará. Revista de Geociências do Nordeste. 2016;2:442.

34. IPECE. (Instituto de Pesquisas do Estado do Ceará). Atlas do Ceará. IPECE: Fortaleza; 2007. 